\title{
YALE
}

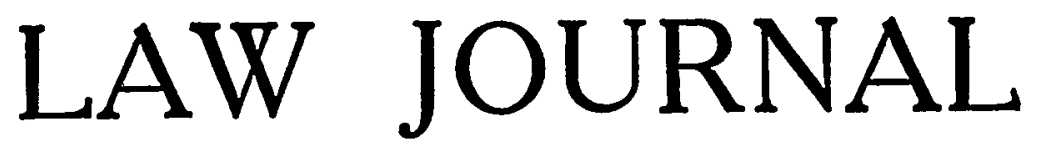

\begin{tabular}{lll} 
Vol. XXVI & MAY, 1917 & No. 7 \\
\hline
\end{tabular}

\section{“DUE PROCESS," THE INARTICULATE MAJOR PREMISE AND THE ADAMSON ACT}

\section{I}

\section{INTRODUCTION}

Many acts of the legislature require persons to expend money or to be curtailed in their liberty of contract, and impose a fine or imprisonment, or both, if the act be not obeyed. They plainly deprive persons of their liberty and property without any other process than the legislative command itself. At the same time the deprivation does not go to the extent of being confiscatory. It does not so far prevent a fair profit in a legitimate business or occupation as to drive people out of it. The much talked of Adamson Law is an act of this sort. It takes the property of the railroads by requiring for a few months the same wage for eight hours work that was paid for ten hours, and by imposing a fine if this provision is not obeyed. It deprives the railroads of their liberty because it interferes with their liberty to contract with their employees as to wages. The only process is the legislative command itself. No point, however, was made in the case recently decided by the United States Supreme Court that the deprivation of liberty and property was confiscatory.

To avoid an act of the legislature, it is not enough that liberty and property are taken. The taking must be "without due process of law," i. e., without justification. If the act provides no process other than its mandate, the question arises: When is the legislative command, and that alone, "due process of law" and when is it not? 
The first appeal is usually to the "police power." Liberty and property, it is said, are held on such reasonable conditions as may be imposed by the governing power of the state in the exercise of its police powers, and, therefore, an act which falls within the police power is justified, although it deprives some person of liberty or property. I This of course gets us nowhere. To say that acts are "due process" when they are within the police power and not "due process" when they are not within the police power is just a way of saying that they are "due process" when they are, and not when they are not. By the time you have defined "police power" (which, by the way, the courts never define) you might as well have defined "due process."

Some of the efforts of distinguished judges to improve upon the "police power" as a test for "due process" have quite plainly failed. In $C . B$. \& $Q . R$. R. Co. v. McGuire," Mr. Justice Hughes, speaking for the court, and after reviewing cases involving the question of "due process," where the act had been sustained, says:

"The principle involved in these decisions is that where the legislative action is arbitrary and has no reasonable relation to a purpose which it is competent for government to effect, the legislature transcends the limits of its power in interfering with liberty of contract; but where there is reasonable relation to an object within the governmental authority, the exercise of the legislative discretion is not subject to judicial review."

This statement says nothing until it has been determined what is meant by "a purpose which it is competent for government to effect," and by "within the governmental authority." In

\footnotetext{
${ }^{1}$ In Lochner v. New York (I905) I98 U. S. 45, at 53 Mr. Justice Peckham, in delivering the opinion of the court, said: "There are, however, certain powers, existing in the sovereignty of each State in the Union, somewhat vaguely termed police powers, the exact description and limitation of which have not been attempted by the courts. Those powers, broadly stated and without, at present, any attempt at a more specific limitation, relate to the safety, health, morals, and general welfare of the public. Both property and liberty are held on such reasonable conditions as may be imposed by the governing power of the State in the exercise of those powers, and with such conditions the Fourteenth Amendment was not designed to interfere."

2 (IgII) 219 U. S. 549 .
} 
McLean v. Arkansas, ${ }^{3}$ Mr. Justice Day, speaking for the court, said:

"If there existed a condition of affairs concerning which the legislature of the State, exercising its conceded right to enact laws for the protection of the health, safety or welfare of the people, might pass the law, it must be sustained; if such action was arbitrary interference with the right to contract or carry on business, and having no just relation to the protection of the public within the scope of legislative power, the act must fail."

A critical examination of the first part of this statement shows it to be quite as meaningless and useless as a reference to the "police power." The court says the act must be sustained, if a condition of affairs existed (I) concerning which the legislature of the state might pass the law, (2) in the exercise of its conceded right to enact laws for the protection of the health, safety, or welfare of the people. Now who would doubt that, with these conditions and premises assumed under which the law must be valid, it would be sustained? Take the second half of the above statement. The act must fail (I) if such action was an arbitrary interference with the right to contract or carry on business, (2) and having no just relation to the protection of the public within the scope of legislative power. Well, who can doubt that an act about which all these self-proving assertions are true would be invalid? Such statements reveal nothing. The opinions of the court are filled with statements of as little value as these.

Then it has been asserted that an act of the legislature is, in and of itself, "due process" if the deprivation of liberty or property has any substantial and rational or reasonable relation to the promotion of the health, safety, morals, or general welfare of the public or any part of the public. ${ }^{4}$ Conversely it is

\footnotetext{
s (1909) 2II U. S. 539, 548.

${ }^{4}$ In Riley v. Massachusetts (1914) 232 U. S. 67r, 679, Mr. Justice McKenna, in delivering the opinion of the court, said: "The prohibition of the statute under review, it is said, 'is not restricted to times and places which relate to and naturally and logically affect a woman's health, safety or morals or the welfare of herself or the public.' Such are the conditions necessary to the validity of a statute, restricting employment, it is contended, and that those conditions are not satisfied by the statute."

Mr. Frankfurter, in his brief for the State in the Oregon Minimum Wage Case, Stettler v. O'Hara, U. S. Sup. Ct., Oct. Term, Igr6, said: "The validity of the Oregon statute must therefore be sustained unless
} 
said, if the act is arbitrary, i. e., if it has no such relation to any of those objects-it is void. Along with this statement goes the administrative rule that no act is to be declared unconstitutional unless it is clearly so, "beyond a reasonable doubt" some courts have said beyond a "rational doubt." ${ }^{\prime}$ This has been declared to mean that the "violation of a constitutional right ought to be as obvious to the comprehension of everyone as an axiomatic truth, as that the parts are equal to the whole" ; and that "the validity of the law ought not then to be questioned unless it is so obviously repugnant to the constitution that when pointed out by the judges, all men of sense and reflection in the community may perceive the repugnancy." This certainly means that if an intelligent judge in the court of last resort may rationally think that the act in question has a substantial and rational, or reasonable relation to the health, safety, morals or welfare of the public or any part of the public, and in fact does so regard the act, it must be held valid. The question is not whether each judge individually thinks the act has a substantial

the Court can find that there is no "fair ground, reasonable in and of itself, to say that there is material danger to the public health (or safety), or to the health (or safety) of the employees (or to the general welfare), if the hours of labor are not curtailed.' Lochner v. New York (I905)
Ig8 U. S., 45, 6r."

In State v. Clausen (IgIr) II7 Pac. (Wash.) Iror, sustaining the Washington Industrial Insurance Act, the court said: "If, therefore, the act in controversy has a reasonable relation to the protection of the public health, morals, safety, or welfare, it is not to be set aside because it may incidentally deprive some person of his property without fault or take the property of one person to pay the obligations of another. To be fatally defective in these respects, the regulation must be so utterly unreasonable and so extravagant in nature and purpose as to capriciously interfere with and destroy private rights."

${ }^{8} \mathrm{~J}$. B. Thayer, The Origin and Scope of the American Doctrine of Constitutional Law (1893) 7 HARv. L. Rev. I29, I38-142.

'In Ex parte $M^{3}$ Collum (1823) I Cow. (U. S.) 550, 564, Cowen, J. (for the court), said: "Before the court will deem it their duty to declare an Act of the legislature unconstitutional, a case must be presented in which there can be no rational doubt." In the Sinking Fund Cases (1878) 99 U. S. 700, Mr. Chief Justice Waite, for the court, said: "This declaration [that an Act of Congress is unconstitutional] should never be made except in a clear case. Every possible presumption is in favor of the validity of a statute, and this continues until the contrary is shown beyond a rational doubt."

${ }^{7}$ Grimball v. Ross (1808) Charlton (Ga.) I75.

${ }^{8}$ Adm'rs of Byrne v. Adm'rs of Stewart (1812) 3 Des. (S. C.) 466. 
and rational or reasonable relation to the objects mentioned, but whether an intelligent fellow-member of the bench may rationally think that it does.

It is difficult to believe that the Supreme Court of the United States spends any time in serious debate over the application of such a formula. Acts have, indeed, been held to be "due process" because the court could not say that they did not have a substantial or rational or reasonable relation to the health, safety, morals, and welfare of the public, or some part of the public. ${ }^{9}$ But the formula is, nevertheless, quite worthless because some acts which intelligent judges may regard as falling within it have been held invalid, showing that there is a limitation upon the legislative power which is not at all expressed.

In Lochner $v$. New York, ${ }^{10}$ where the ten-hour law for bakers was held void, the act had some relation to the health of persons employed in bakeries, and four judges out of nine thought this was a substantial and rational or reasonable relation. Since intelligent men could take that view, the case must have been decided upon the basis that such was the fact, and that it was not sufficient to sustain the act. So in Adair $v$. United States, ${ }^{11}$ and Coppage v. State of Kansas, ${ }^{12}$ acts which forbade employers to discharge employees because they belonged to a: union, were held void. These acts clearly had a relation to the general welfare of employees (and not unlikely to the public as well) by promoting the existence of unions and collective bargaining between employees and employers. The dissenting opinions make it clear that intelligent men could regard such a relation as substantial and rational or reasonable. The decision must, therefore, go on the ground that this was insufficient to sustain the act. In Smith $v$. Texas, ${ }^{13}$ an act which prohibited any person from acting as a conductor on a railroad train without having for two years prior either worked as a brakeman or conductor

\footnotetext{
'In McLean v. Arkansas (I909) 2II U. S. 539, at 550, Mr. Justice Day in delivering the opinion of the court said: "We are unable to say .... that this law had no reasonable relation to the protection of a large class of laborers in the receipt of their just dues and the promotion of the harmonious relations of capital and labor engaged in a great industry in the state."

${ }^{10}$ (1905) 198 U. S. 45.

21 (1908) 208 U. S. I6r.

12 (1915) 236 U. S. I.

${ }^{13}$ (I914) 233 U. S. 630.
} 
on a freight train, was held void. This act clearly had a relation to the efficiency of conductors, and, therefore, to the safety of the public and other employees. Again, the dissent indicates that intelligent men might regard this relation as substantial and rational or reasonable. The case, therefore, goes on the ground that in spite of such a situation the act is void. In Chic. Mil. \& St. P. R. R. v. Wisconsin, ${ }^{14}$ an act which required the railroad company to leave the upper berth up when it had not been disposed of and the lower berth was occupied, was held void. This act had some relation to the convenience and comfort of the public. The dissent makes it clear that intelligent men could regard this relation as substantial and rational or reasonable. The decision, therefore, must go upon the ground that rational opinion that such a relation existed is insufficient to sustain the act.

In Lochner $v$. New York, ${ }^{15}$ the court puts a number of hypothetical cases where it concedes the act would have had a relation to the health of employees, and where intelligent men might regard the relation as substantial and rational or reasonable, and where, nevertheless, the act must be regarded as beyond the power of the legislature. It is assumed by the court that an act prohibiting lawyers or bank clerks or others from contracting to labor for their employers more than eight hours a day would be invalid, although it might rationally be said by intelligent men that the work of such employees was carried on in offices lighted by artificial light and was therefore unhealthy, and that such an act had reference to the public health. It is assumed by the court also that acts regulating the hours of labor of employers and acts forbidding doctors, lawyers, scientists, and other professional men as well as athletes and artisans to fatigue their brains and bodies by prolonged hours of exercise would be invalid, although intelligent men might rationally think such acts would have a relation to the strength, robustness and fighting qualities of the population in which the state is vitally interested. In the argument on the Adamson Act one of the justices asked counsel for the government if an act of Congress which voted-Mr. Debs $\$ 50,000,000$ to call off a railroad strike would be valid. Counsel answered that it would! This was a clear reductio ad absurdum of his position that any act, which an

${ }^{14}$ (I9I5) 238 U. S. 49 I.

${ }^{15}$ (I905) I 98 U. S. 45. 
intelligent man might rationally think had any substantial and rational, or reasonable relation to the public safety, or general welfare would be valid. Imagine arguing that an act which abolished all interstate railroad transportation was valid because an intelligent man might rationally think it had a substantial and rational, or reasonable relation to the public safety, or the safety of the employees, since so many thousands of the public and the railroad employees were killed or maimed every year as a result of interstate railroad transportation, and because learned scientists and statisticians had made it plain that, while such losses might be reduced, they must always occur. Imagine anyone solemnly arguing that an act abolishing the steel industry, or coal, iron, and copper mining would be valid for similar reasons. Imagine anyone attempting to sustain an act legislating out of existence our entire industrial system and requiring a reversion to primitive agricultural conditions, because, forsooth, some intelligent man could rationally think the act had a relation to the safety and health of the public and employees! It does not require any great degree of insight to perceive that the continuance of railroad transportation, the steel and mining industries, and indeed the whole modern scheme of industrial and commercial organization, is essential and necessary to the existence of our social order. These, and many other activities, must go on, no matter if thousands do lose their lives, and their health, and their morals every year as a result, and must continue to do so.

If the test of "due process" is whether a majority of the court individually think that the act has a substantial and rational or reasonable relation to the safety, health, morals, or welfare of the public, or any part of the public, then what are the criteria for determining whether the "substantial and rational" or "reasonable" relation exists? With reference to what views is the reasonableness of the relation in question or its substantial quality to be determined? When the court frequently splits on whether there is such a "reasonable" or "substantial" relation, it is clear that these criteria are of the utmost importance. That the court has failed to articulate them is clear from the dissenting opinion of Mr. Justice Holmes in the Lochner case. ${ }^{16}$ He says (speaking, it is assumed, of whether an act is "due process" or not):

\footnotetext{
${ }^{16}$ (Ig05) I98 U. S. $45,76$.
} 
"The decisions will depend on a judgment or intuition more subtle than any articulate major premise."

A moment later in the same opinion we have the concession that there may be some fundamentals which the legislature cannot touch:

"I think that the word liberty in the Fourteenth Amendment is perverted when it is held to prevent the natural outcome of a dominant opinion, unless it can be said that a rational and fair man necessarily would admit that the statute proposed would infringe fundamental principles as they have been understood by the traditions of our

Here is the whole story behind the failure of all formulae connected with "due process" and all the meaningless and circular statements as to what acts are and what are not "due process." In determining whether an act has a substantial and rational or reasonable relation to the enumerated matters, the court has in mind a background of "fundamental principles" which are beyond the reach of any legislative power. What these are and how they affect the question of the substantial or reasonable relation of the act to the enumerated objects depends upon "a judgment or intuition, more subtle than any articulate major premise." They are indeed the inarticulate major premise itself.

Progress in determining whether the command of the legislature is, or is not, in and of itself "due process of law" will be made only when less reliance is placed upon mere "judgment" or "subtle intuitions," and more upon the effort to expound and articulate what is now "the inarticulate major premise." Who is to do this? The court evidently does not intend seriously to try. Just because, if it spoke, its utterance would be authoritative and binding for the future, perhaps it should not attempt to do so. The task will, therefore, fall upon those who are outside the judicial conference chamber and who speak without authority even when they speak what for the time being may approximate the truth. They must speculate about the matter as best they can. In order that a start may be made in such speculations, the following are submitted. 
SUGGESTIONS FOR A TEST

It is hardly open to question that the fundamental principles and the inarticulate major premise to which Mr. Justice Holmes refers are in part at least the fundamental principles of thought and action upon which the existence of our social structure rests. The court does not deal with matters of legislative expediency. It concedes that legislation which is merely unwise is not for that reason void. It deals with questions of power. It must be that the inarticulate major premise in the test of what is "due process" has to do with such serious and ultimate matters as the fundamentals of our social order. Only such as these are to be protected by the court from the exercise of the legislative power. The articulation of the major premise most probably consists in putting into intelligible words the ideas for the time being of the judges as to what are the fundamentals of the social order which must be placed beyond the reach of the legislature. There is, of course, a difficulty about articulating for the judges what they do not publicly articulate for themselves and for us. With the aid, however, of a "judgment" and a "subtle intuition" which ought not to be the exclusive attribute of the judicial office, the following attempt is made to state some of the fundamentals of the social order as, it is conceived, they may lie in the minds of the majority of the judges.

Society rests upon success in commerce and industry. Even agriculture tends to become industrial. The social structure depends for its life upon what people are doing for the most part from six o'clock in the morning to six o'clock at night.

For the running of the social structure there are two classes of people-the individual labor unit and the individual managing unit. The industrial population may be seen as an army of workers, the many being the rank and file, known as the labor units; and the officers being the managing units. If "labor and capital" means anything, it means the division of the population into labor units and managing units. The world is run by labor, whichever kind it may be.

In an army the authority of the officers rests upon physical coercion enforced by the rank and file pursuant to the orders of officers or leaders. In this commercial and industrial organiza- 
tion of society, authority rests upon the attributes of the private ownership of property. These arise and are protected in the first instance, at least, by governmental sanction. Ultimately they rest upon the support and approval of the rank and file; namely, the labor and managing units of all classes. The managers own the property, or they represent the owners, and wield the power which that ownership confers.

The managers in this industrial and commercial organization of society are selected upon a competitive basis. Men compete to become the managers of business. It may appear to the unthinking as if they competed for money. This is not really so. They compete for success in the management of property. That success means the making of profits, and the rewards of successful management are naturally measured in terms of privately owned property. But the successful manager controls vastly more property than he can own or acquire. As more property is created or its value is enhanced it still remains in the hands of the manager class. Many owners of property are retired managers, or the first, second, or third generation from some successful super-manager whose rewards were large enough to remain together for a considerable time. But the control of property (whoever owns it) remains in the active managers and must remain there in order to confer that authority and power which the managers require in order to attain successful management. Even when the labor units engaged in a given enterprise wish to own and run it, they must own the property necessary. They must delegate the power which that ownership confers, upon managers and leaders who can do the managing successfully and exercise the authority necessary for successful management.

The unionization of labor units if carried to completion means only that a new class of managers will have been created. Formerly the managers of property were the managers of such labor units as were required in their business. Under the labor leader, labor units are combined, and the labor manager takes the place of the manager of the plant employing labor. The property manager then deals with the labor manager as the manufacturer of steel products deals with the manufacturer of his raw material. He buys his labor through the labor managers as he would buy his raw material through the steel corporation. If both were managed with equal skill and fairness he would 
no more think of asking that the labor manager be abolished, than he would ask that the steel corporation manager be abolished and the business of manufacturing steel be disrupted. The difficulty, however, in the development of the labor manager is that he has no source of authority except the immediate consent and acquiescence of the labor units themselves. The state, as yet, gives him no aid through the specific performance of agreements with the labor units, or the enforcement of the rules of the labor organization. As a practical matter the labor manager, with the consent or acquiescence of the main body of labor units, resorts, not infrequently, to what is now unauthorized force against individuals to enforce the rules promulgated by the labor manager himself. To legalize this involves the exercise of the authority of the state specifically to enforce contracts between labor units and the labor managers. That means approximately the same sort of slavery for the labor unit as now exists for inanimate property. That is the difficulty, not the solution.

There are three paramount evils in the present commercial and industrial organization of society. They are the selfishness, and the stupidity of the managers, and the fact that the rewards of successful managing are in many cases out of all proportion to what the managers are willing to work for.

Considered de novo, the legislative power is the legitimate means of correcting mistakes of persistent stupidity and shortsighted selfishness on the part of the managers. It is the legitimate means of compelling all to do that which the wiser are ready to do, but the more stupid and the more selfish are unwilling to attempt, and, therefore, not infrequently prevent action by any. The legislative power is the legitimate means of cutting down the rewards of successful management so that they are not out of all proportion to what the successful manager is willing to take. So far as the legislation in question tends to accomplish these objects, it should be sustained. On the other tand, so far as it tends to substitute a legislative fiat for the judgment of the managers, and thereby place the management of our industrial and commercial units in the hands of the legislature-so far as it tends to undermine the manager's chances and motives for successful management, or to impair the competitive system by which the managers are selected, or to interfere with the ownership and distribution of private 
property by which the manager's authority is maintained, the legislation in question is a menace to the social structure, and, therefore, inimical to the general welfare and should be condemned. What the court obviously has to do is to balance these opposing tendencies of any given legislation and to determine its predominant effect. If its predominant effect is that of correcting the mistakes of persistent stupidity and shortsighted selfishness on the part of the managers, it should be valid. If its predominant effect is that of reversing some fundamental principle upon which the social order rests, it should be void.

On the whole the actual results reached by the court justify this line of distinction.

Why, for instance, if the act be confiscatory, is it held to be not "due process?" It is not simply that confiscation is abhorrent. There is no objection to prohibiting the liquor business and thereby causing loss which in general would be regarded as confiscatory. It is because confiscation destroys business. It prohibits business by making it unprofitable. When, therefore, the business is one required by, or consistent with, the exigencies of the social order-as distinguished from the liquor businessan act prohibiting it, whether directly or by confiscatory burdens, is not "due process." Assuming, therefore, that the manufacture and sale of oleomargarine is a legitimate business, dealing in a wholesome and useful article of food to the increasing many who cannot afford to buy butter, its absolute prohibition would not be "due process." Even if there were danger of fraud by the substitution of oleomargarine for butter, nevertheless, in balancing the importance to society now and hereafter, of permitting a useful and legitimate business in an important article of food to be carried on free from the confiscatory action of the legislature, against the desirability of eliminating by the entire prohibition of the business, all danger of deception, the former consideration should certainly prevail. The result reached by the New York Court of Appeals in the Marx case, ${ }^{17}$ holding such an act void, is sound. The opposite conclusion reached by the United States Supreme Court in the Powell case, ${ }^{18}$ is plainly the result of a failure to balance the interests correctly. The court took in the danger of fraud upon the few and forgot the danger of malnutrition to the many.

${ }^{13}$ People v. Marx (I885) 99 N. Y. 377.

${ }^{13}$ Powell v. Pennsylvania (I888) I27 U. S. 678. 
A number of acts plainly interfering with business, sustained by the United States Supreme Court as "due process," are given by the court itself in a recent opinion ${ }^{19}$ : legislation limiting employment in underground mines or workings, and in smelters and other institutions for the reduction or refining of ores or metals, to eight hours a day except in cases of emergency $^{20}$; legislation requiring the redemption in cash of store orders or other evidence of indebtedness issued in payment of wages $^{21}$; legislation prohibiting the employment of women in laundries more than ten hours a day ${ }^{22}$; legislation making it unlawful to contract to pay miners employed at quantity rates upon the basis of screened coal, instead of the weight of the coal as originally produced in the mine. ${ }^{23}$ The Supreme Court has recently sustained the California act limiting the hours of labor of women in certain employments to eight hours in one day, or a maximum of forty-eight hours a week. ${ }^{24}$ The court has sustained two Arkansas statutes, ${ }^{25}$ requiring full train crews for railroad trains. In Noble State Bank v. Haskell, ${ }^{28}$ the court sustained the validity of the Oklahoma Act subjecting state banks to assessments for a depositors' guarantee fund. All these acts in a degree interfere with the managers' freedom to manage according to their judgment and opportunity. All in a degree tend to substitute the legislative fiat for the will of the managers. They tend to some extent to undermine the managers' chances and motives for successful management. At the same time they tend to counteract the persistent stupidity and short-sighted selfishness of the managers themselves. They tend to compel all alike to do what the more enlightened are willing to concede is for the best interests of the business. They tend to compel that co-operation or common action by all the members of a group, which is desirable in the interests of the business itself as well as the general welfare, but which cannot be obtained without the compulsion of law, because some at

${ }^{10}$ Chicago, B. \& Quincy R. R. Co. v. McGuire (Igri) 2I9 U. S. 549, 568.

${ }^{20}$ Holden v. Hardy (I898) I6g U. S. 366.

${ }^{21}$ Knoxville Iron Co. v. Harbison (IgOI) 183 U. S. I3.

${ }^{22}$ Muller v. Oregon (1908) 208 U. S. 4I2.

${ }^{23}$ McLean v. Arkansas (I909) 2II U. S. 539.

${ }^{24}$ Miller v. Wilson (1915) 236 U. S. 373 ; Bosley v. McLaughlin (I9I5) 236 U. S. 385 .

${ }^{25}$ Chic. Burl. \& Q. R. R. Co. v. McGuire (IgII) 2I9 U. S. 549.

${ }^{20}$ (IgII) 2I9 U. S. I04. 
least would never subscribe to the plan voluntarily. The latter tendencies fixed the predominant effect of the acts in question, and they were, upon the balancing of the interests, sustained.

This method of analysis is especially well illustrated in the Oklahoma Depositors' Guarantee Fund case. The act under consideration there assessed all the state banks for a guarantee fund to pay the depositors of any bank that failed. From the point of view of the individual successful banker, this was an unconscionable interference with his business. It compelled him to support his weak competitors. It required the successful to maintain the credit of the unsuccessful, or less successful, competitor. This attitude, however, furnishes an excellent example of persistent stupidity and short-sighted selfishness. The success of banks and the banking business as a whole depends upon stability and security of depositors. It is that which brings in the depositors from local and distant sources as well as from the stocking and from the safe. Of such overwhelming importance is this stability and security of depositors to the banking business, that in times of failure and panic in great banking centers, the strong banks in their own interests have felt compelled to step in and protect depositors. Is it an overstatement to characterize as stupid and short-sightedly selfish the refusal of individuals to recognize this fact, and their insistence that the continued failure of weak banks was a benefit to the strong ones and to the banking business in general? Yet such an attitude was certain to continue on the part of many individuals engaged in the banking business, until some unusual course of events demonstrated their folly. Co-operative effort to achieve stability and security in the banking business for its own advantage would, therefore, be indefinitely postponed. Under such circumstances, the legislature steps in to make possible at once that which is for the best interests of the business itself, by compelling those to co-operate who would otherwise refuse to do so. It is not advisable to lay the principal stress on the benefit of the legislation in question to the public apart from the benefit to the business. A benefit to the public which hurt the business would in the long run be a delusion and against the public welfare. If the act assists the business and at the same time benefits the public-indeed, if it assists the business because it benefits the public-its predominant effect is 
such as to require it, on any theory of balancing of interests, to be sustained.

On the other hand, the moment the predominant effect of the act was to substitute legislative managing for the managing by competitively selected industrial leaders, or to substitute legislative selection of managers for competitive selection, it was held void.

In the Lochner case, ${ }^{27}$ an act limiting to ten hours a day the hours of labor for bakers was held void. The majority individually thought that the act had no "substantial and rational" or "reasonable" relation to the health or welfare of the public or any part of the public, because upon a balancing of the interests affected, its predominant effect was to substitute a legislative fiat for the judgment of the managers in the baking industry. There was no showing that this judgment was so persistently stupid and short-sightedly selfish as to justify the interference of the legislature in the management of the business.

In the $A d a i r^{28}$ and Coppage ${ }^{29}$ cases, acts which forbade employers to discharge employees because they belonged to a union were held void. These acts clearly attempted to substitute the legislative fiat for the judgment of the managers in a most vital matter; namely, what persons the managers should employ, and on what terms employees should be retained. If sustained, the way would be open for acts which would substitute the will of the legislature for the judgment of labor managers as to when employees should quit, or the terms upon which they should work, or who should be employed at all. This last, by controlling the group of workers from which managers must be largely recruited, would jeopardize the competitive method of selecting the managers themselves. What was there to weigh against these serious objections to the act? Practically nothing. The act had no relation to the health, morals, or safety of anyone. It was hard to say that the managers, in so far as they resisted the unionization of employees and collective bargaining through labor managers, were persistently stupid and short-sightedly selfish, and that for this reason their opposition to unions should be curbed. Perhaps the time may come when such opposition will be regarded as so stupid that it may be

${ }^{2}$ Lochner v. New York (1905) r98 U. S. 45.

${ }^{2}$ Adair v. United States (1908) 208 U. S. I6r.

${ }^{2}$ Coppage v. State of Kansas (rgI5) 236 U. S. r. 
interfered with by the legislature. But evidently no case of that sort was made out to the satisfaction of the court. There was, therefore, nothing to outweigh the considerations against the acts. Their predominant effect was to violate fundamental principles upon which the social order rests. They had, therefore, no "substantial and rational" or "reasonable" relation to the public welfare and were consequently void.

In Smith v. Texas, ${ }^{30}$ an act which prohibited any person from acting as a conductor on a railroad train without having for two years prior either worked as a brakeman or conductor on a freight train, was held void. The legislation here involved was a very obvious regulation of the conditions upon which men were employed. It had, of course, some connection with the efficiency of conductors, and, therefore, with the safety of the public. At the same time it was apparent that upon a balancing of interests, the safety of passengers and employees, to be promoted by securing, by means of this act, more efficient conductors, was slight as compared with the setting aside by the legislature of the fundamental principle that industrial and commercial leaders shall be selected by the competitive method. Such competitive selection cannot be accomplished unless the avenues of promotion remain open. The predominant effect of the act was clearly to substitute the action of the legislature for the competitive method in the selection of managers. Hence, the act had no "substantial and rational" or "reasonable" relation to the public safety. That this was the precise ground of the court's decision appears from the following language of the court, delivered by Mr. Justice Lamar:

"If the statute can fix the class from which conductors on freight trains shall be taken, another statute could limit the class from which brakemen and conductors on passenger trains could be selected, and so, progressively, the whole matter, as to who could enter the railroad service and who could go from one position to another, would be regulated by statute. In the nature of the case, promotion is a matter of private business management, and should be left to the carrier company, which bound to serve the public, is held to the exercise of diligence in selecting competent men, and responsible in law for the acts of those who fill any of these positions."

(1914) 233 U. S. 630. 
In Chic. Mil. \& St. P. R. R. v. Wisconsin, ${ }^{31}$ the Supreme Court held void an act which required upper berths in sleeping cars, when not engaged, to be left up. This had some relation to the convenience of the travelling public. On the other side, however, the act was a clear substitution of the legislative will for the judgment of railroad managers in the matter of running sleeping cars. Nor was any case made that the act was justified by the persistent stupidity or short-sighted selfishness of the sleeping car managers. On the contrary there was evidence that the convenience and welfare of travellers was served in some degree by the practice of putting the upper berth down whether engaged or not. No case was, therefore, made against the act. The court said:

"The right of the State to regulate public carriers in the interest of the public is very great. But that great power does not warrant an unreasonable interference with the right of management or the taking of the carrier's property without compensation."

Mr. Frankfurter's argument in support of the Oregon TenHour Law for $\mathrm{Men}^{32}$ in certain occupations and the Oregon Minimum Wage Act for Women, ${ }^{33}$ really proceeds upon the distinction suggested. He has to admit at once, of course, that the acts in question interfere to a considerable extent with the manager's freedom in bargaining with labor as to the terms of employment. The legislature is in some degree at least substituting its fiat for the judgment of the managers of industry. The real difficulty is in the attempt to show on the other side, that the managers are persistently stupid and short-sightedly selfish in not adopting these very measures; that by their adoption the industry itself would be better served, production increased, and employees and employers both more prosperous and better satisfied; that the more enlightened managers are ready to take these very steps, when all alike are required to do so; that because some will not take the steps required by the legislation in question, practically all are prevented from doing so. If this position could be maintained, on the facts, the court would be

22 (1915) 238 U. S. 49I.

Bunting v. Oregon (Apr. 9, 1917) U. S. Sup. Ct., Oct. Term, rgI6. No. 38 .

${ }^{*}$ Stettler v. O'Hara, U. S. Sup. Ct., Oct. Term, I9I6. 
bound to say that its predominant effect was to uphold the social order and the general welfare and not to destroy it. It would, therefore, say the acts in question did have a substantial and rational or reasonable relation to the public health and welfare and were valid. ${ }^{33 a}$

\section{III}

FUNCTION OF THE COURT IN DETERMINING THE QUESTION OF "DUE PROCESS"

The function of the Supreme Court in exercising a veto upon legislation which tends to imperil the fundamentals of the social structure is not unique. The judicial method of performing the function may be unusual, but the function itself is not unknown in well regulated modern democracies. England which has constantly been held up to us as a government in which Parliament is omnipotent; and where courts do not declare laws unconstitutional, furnishes a striking example of the existence of this function. In the omnipotence of Parliament is involved the concurrence of the House of Lords. That body is made up principally of the representatives of property and business interests. One of its chief functions has been to see that the popular assembly did not overturn the fundamentals of the existing social order. In England, therefore, you will find in place of our Fifth and Fourteenth Amendments, and our Supreme Courts declaring acts of Congress and of the states unconstitutional, a second chamber directly representing property and business interests and having, until recently at least, an absolute veto upon the acts of the popularly elected House. Such second chambers are naturally unpopular, and fail sooner or later. They fail if they do not perform this function of standing between the popular will and the fundamentals of the social structure. They are quite likely to fail if they do. When the fundamentals of the social order change, a second chamber which persists in protecting the fundamentals of the past which no longer exist, must, temporarily at least, be set aside. The Supreme Court of the United States, through its power to declare laws unconstitu-

${ }^{33 a}$ Since this article went to press the Oregon Ten Hour Law for Men has been sustained by the United States Supreme Court by a vote of five to three. The Oregon Minimum Wage Act for Women was sustained by an evenly divided court, no opinion being rendered. 
tional in obedience to the Fifth and Fourteenth Amendments, is our substitute for a second legislative chamber for the United States and the states. The function which it performs is a necessary and proper one in all governments where the legislative power is wielded by a popularly elected assembly or assemblies. When the function of the court is exercised faithfully, the court must incur unpopularity. If the court did not become, to some extent at least, unpopular, there would be raised a suspicion that it was not performing one of its most important functions. So long, however, as the court confines itself to the protection of the actual fundamentals of our social order from assault by the majority, its continued support by the majority is to be expected.

It has been asserted that because the court cannot apply force to the carrying out of its judgments, its function in declaring laws unconstitutional should be curbed to the vanishing point. All second chambers are weak. Physically they are helpless. The House of Lords could not originate a budget or control expenditures. It did not control the Army or the Navy. It exercised its power neither by force, nor the suggestion of force, but by reason of the respect of Englishmen for a constitutional authority and by virtue of the social prestige of its members, their ownership of property and success in the commercial and industrial world. It is desirable that second chambers should be weak, so far as the control of force is concerned. Such weakness is the best guaranty that the members will use their heads and not their arms. Our Supreme Court similarly maintains its position, and the exercise of its most important function, because of the respect in which we hold constitutional authority, and our belief in the integrity and fairness of the judiciary; and perhaps also because the judges are not the leaders of the business world and the owners of property, but are regarded as having a superior habit of judicial insight.

Up to this point stress has been laid upon the fact that our Supreme Court exercises much the same function in our state and federal governments that the House of Lords does in England. It is time to point out that the method of its exercise is very different. The House of Lords considers the act before it can be enforced by public officers as law. It is entitled to exercise its veto upon any ground and is bound by no rule of stare decisis. It may act like any legislative chamber in proposing amendments. Our Supreme Court, on the other hand, func- 
tions only after the act has presumably become law and is being enforced. Furthermore, it vetoes or sustains the act as a whole, or in part if it be separable. It has no power to act like a second legislative chamber in proposing amendments. But most important of all, it attempts to proceed like a court in accordance with general principles. It looks to its past decisions and to a proposed decision as creating a legalistic generalization. This may cause an act, insignificant in scope and extent when taken by itself, to fall within a generalization which will cause the act to fail. For instance, the act requiring conductors on railroads to be selected only from those who had served as brakemen, ${ }^{34}$ might, in and of itself, be regarded as harmless. Yet sustaining it would have established a generalization that the legislature had a free hand to interfere with our industrial and commercial system, with the way in which its leaders manage, and the competitive struggle by which leaders are selected. The argument that sustaining a given act leads to a generalization which cannot be permitted, should be distinguished from the discredited argument based upon abuse of power. With the abuse of power, the court does not attempt to deal. It is the generalized definition of power which the court is supposed to elucidate.

The effort of courts in declaring laws unconstitutional to act in all respects like a court exercising its judicial function has broken down in one important respect. The court, while it is very wary not to make a decision that will lead to a generalization which is not permissible, is very careful not to proceed according to any generalization of its own. This is only reasserting the main point of this article, that in the definition of what is "due process" the court leaves the major premise always inarticulate. That means that there can be no authoritative and usable generalization about what is, or what is not, "due process." To leave the major premise inarticulate and to reach results on "judgment" or "intuition" is just a scheme for not having any rule of law or legal generalization which is susceptible of application. It is a device for leaving the court with a wide discretion to do what it thinks best. The court hardly takes this position because it feels unable to articulate the major premise. It is undoubtedly difficult to do so, but it is not impossible. Certainly it is not impossible to make some

${ }^{34}$ Smith v. Texas (IgI4) 233 U. S. 630. 
progress toward that end. The real objection is that it would involve a reference to what the court must regard as the fundamentals of the social order, and particular cases would begin to elucidate what those were. The decisions would, if treated like other judicial decisions, have an effect as stare decisis. Every opinion on a question of "due process" would tend to become a law. ${ }^{35}$ This would be most inconvenient, because the court might make a mistaken decision as to what was a fundamental of the social order, or in a period of time, what the court had held to be a fundamental of the social order, might change, or it might more clearly be perceived that it was not a fundamental at all. With prior decisions being adhered to and followed on the principle of stare decisis, the rules as to what the legislature could not do might become too rigid and inflexible and result in a justifiable dissatisfaction with the court and its function. On the other hand, so long as the major premise remains inarticulate, the court has a free hand in spite of the rule of stare decisis to give effect at all times to what it regards as the dominant opinion with respect to what are the fundamentals of the social order. These considerations require the court either to give up the doctrine of stare decisis in cases involving "due process" or to leave the major premise inarticulate. It is submitted that it would be better to take the former step, and then speak with more reality and freedom in opinions, so that the major premise might become, to a greater degree, articulate. It is hardly fair, by wilfully leaving the major premise inarticulate, practically to abrogate in this class of cases the principle of stare decisis also.

The fact that the major premise is left inarticulate explains very clearly the non-existence or futility of the rule of administration which Professor Thayer so strongly insisted upon; namely, that an act of the legislature should only be declared unconstitutional when it appeared to be so, clearly and beyond a reasonable doubt, or beyond a rational doubt. ${ }^{38}$ So long as the major premise remains inarticulate, how can anyone ever say that there is any reasonable or rational doubt concerning the result reached by any majority which holds the act unconstitutional?

\footnotetext{
${ }^{s}$ In Lochner v. New York (I905) Ig8 U. S. 45, Mr. Justice Holmes said in his dissenting opinion: "Every opinion tends to become a law."

${ }^{*}$ See J. B. Thayer, Origin and Scope of the American Doctrine of Constitutional Law (I898) 7 HARV. L. REV. I29, I38-I42.
} 
If the majority proceeds upon one inarticulate major premise and the minority upon another, it may be that no intelligent man acting rationally would differ from either. If all the members of the court adopted the same major premise the entire court might agree. If, when the major premise becomes articulate, it involves a balancing of the interests-as when the effect of an act in interfering with the freedom of the managers to manage is weighed against the stupidity and selfishness of the managers-there is little room for the operation of any rule that if two men, acting rationally, differ, the act must be sustained. With such a major premise, judges must decide the way they estimate the evidence and the way they balance the interests. Each might say, that if he personally had any doubtif the considerations were equally balanced-the act must, in his opinion, be sustained. But it would be quite unthinkable that a judge should sustain the act because a fellow-member of the bench, in balancing the interests, came to the conclusion that the act was valid. Such a rule would mean that every act would be sustained if one judge out of nine could rationally say that upon balancing the interests, those in favor of the act prevailed. The judges plainly have never acted upon any such basis. On the contrary, the constant dissents are explainable only on the ground that different judges have adopted different inarticulate premises or that they have, in fact, been balancing the interests, and have not agreed as to the result reached in so doing.

If the function of the court had been to determine each case by the application of a formula, the major premise of which was articulate, the same act might have been brought up for consideration in different cases under different records, presenting in each an entirely different case with respect to the application of the major premise. At the same time when an act was sustained through the efforts of the state in making a special record on the evidence in one case, the act might fail when attacked in the next case if no such record were made. This would produce the anomaly of the act being sustained on one record as between the state and one party, and held invalid upon the record as between the state and another party. The state would be kept busy constantly repeating the same evidence in support of the act as often as it was attacked. Courts of last resort would be kept busy examining records on the evidence and considering much material introduced under the guise of sources of which the court was asked to take judicial notice. The court 
might have to hear several different cases involving the same act, each arising at a different time, and upon a different record before the interests affected were satisfied that upon the rule of stare decisis the act would be valid or invalid for everyone. These inconveniences have been avoided to a considerable extent by keeping the major premise inarticulate and rendering it obscure that the court was really engaged in balancing the interests. The legal profession under these circumstances has generally thought that the case was fully presented when the act was before the court with such facts as the court took judicial notice of. Such a misconception, however, has militated rather more against than for the validity of acts of the legislature. What the court took judicial notice of was usually valuable in showing that the act deprived someone of liberty or property and interfered with the function of managers to conduct business according to their own judgment and opportunity. The few who have been astute enough to appreciate the misconception have had an advantage not possessed by the many. This has operated, on the whole, to give an advantage to the property interests seeking to set aside an act of the legislature not possessed by those who represented the state.

If a business like that of manufacturing oleomargarine, or baking powder containing alum were jeopardized by prohibitory legislation, counsel attacking the act could be relied upon to put in evidence proof that alum was a perfectly harmless substance in baking powder, or that oleomargarine was an entirely healthy and proper article of food as the case might be. In the Upper Berth case, ${ }^{37}$ counsel for the railroad were not above introducing evidence and securing a finding of the trial court "that the lowering of upper berths does not injure the lives, health, or safety of persons occupying the lower berths and that keeping the upper berth closed will not add to the comfort of the public generally." But when hours of labor statutes have been under consideration, those supporting the act seem, in the general run of cases, not to have insisted as part of their case upon a complete investigation of the industry affected, in order to determine whether the managers were persistently stupid or short-sightedly selfish in the hours of labor which they endeavored to maintain. For instance, suppose an Eight-Hour Law for Women in Factories-principally textile-were under considera-

${ }^{87}$ Chic. Mil. \& St. P. R. R. v. Wisconsin (I9I5) 238 U. S. $49 \mathrm{r}$. 
tion, would any state's attorney think to put in evidence, by witnesses under oath, subject to cross-examination, the situation in the locality where the law was operative as to the speeding up of machines, or the concentration of attention required by reason of new inventions in machines, or the larger number of machines that a single operative was called upon to tend, in order to demonstrate the far greater nervous strain upon the operative at work in the mills than they were under a few years ago? Counsel for the state, in the cases involving the Oregon Ten-Hour Law for Women, ${ }^{38}$ the Oregon Ten-Hour Law for Men, ${ }^{39}$ and the Oregon Minimum Wage Law for Women, ${ }^{40}$ only produced data and statistics which the court was asked to take judicial notice of, and these had little to do with conditions in Oregon.

The failure to articulate the major premise has, it must be conceded, some administrative advantages, and the articulation of the major premise is not without its administrative disadvantages. If the major premise is to be made articulate, some means must be devised by which the question of "due process" shall not be passed upon by any court without the presentation to it of a proper record upon the issue involving the balancing of interests. When such a record is once made, the finding upon which the court proceeds should be admissible in all other proceedings involving the same issue and should be prima facie evidence of the facts so found. This probably means that a permanent judicial officer must be attached to the courts, qualified to make such investigations, equipped with resources to do so, and having the power and the duty to proceed independently of the parties as well as in connection with their efforts.

Nothing is gained by bickering over whether the court's action in declaring legislation unconstitutional is political or judicial. It might be called a political function on the ground that the court, like second chambers generally, was protecting the fundamentals of society from the sudden assaults of a temporary popular majority. One is bound, however, to concede that the function of the court is exercised under some forms and limitations which pertain to the judicial function. But when the major premise of any test of "due process" remains inarticulate, so

${ }^{33}$ Muller v. Oregon (I908) 208 U. S. 4I2.

${ }^{3}$ Bunting v. Oregon, supra.

"Stettler v. O'Hara, supra. 
that the court is not bound by any legal formula or generalization, when no evidence is taken or record made to determine whether the act in question falls within any legal formula or generalization with regard to what is "due process," and when judicial notice of facts, "judgment," "intuition," and visceral sensations supply the place of the inarticulate major premise and the application of it to the facts, the judicial aspect of the court's function diminishes to the vanishing point, and the function itself becomes suspiciously like that of the ideal legislator. If, however, we agree that the court has a function, and what that function is, and the mode of its exercise, we will have no need to enter upon the futile dispute as to whether the function is to be called one name rather than another. If we do not agree what the court's function in fact is, or the mode of its exercise, then emphasizing different names may only accentuate a disagreement which should be made more plain and precise.

IV

APPLICATION OF THE FOREGOING TO THE ADAMSON ACT

Without these preliminaries, or others upon similar lines, an act like the Adamson Law canuct he dealt with very intelligently. With them such an act can be disposed of rather shortly.

If the act (without, however, being confiscatory) is one which merely raises wages-as if it read that during eight months from January Ist the wages of all railway employees shall be 20 per cent higher than before-it would clearly be void. It might be conceded that such an act had some relation to the safety and general welfare of the public in a most vital particular; namely, in keeping its transportation service going. No doubt intelligent men could regard the relation as rational and substantial or reasonable. On the other side, it is clear that the act strikes directly at one of the fundamentals of our social structure; namely, the freedom of the leaders and managers of industry to buy and sell labor or commodities at prices fixed by economic conditions rather than by the fiat of the legislature. This is the freedom of the leaders of industry to manage in accordance with their judgment and opportunity, rather than in accordance with the will of the legislature. When the two effects of the act are balanced, it is clear that the predominant 
effect is to overturn a fundamental principle upon which the social order rests. As a means of keeping the transportation system of the country in operation, the act is temporary, and, from the beginning, entirely speculative. So far as it lays open to the unrestricted action of the legislature a fundamental of our social structure, it is permanent.

It is true that the government might take over the ownership of the railroads and fix wages on a political basis instead of an economic one, but while it leaves the railways in the hands of private owners to be managed as private enterprises, it must not impair any fundamental principle of the code upon which such management rests. It has been suggested ${ }^{41}$ that the power to regulate wages of railroad employees follows from the power actually being exercised to regulate their rates. This entirely overlooks the fact that the function of the court is based upon the protection of the fundamentals of our industrial order from the momentary acts of a popular majority. Hence, the fact that the legislature has control of rates is a reason above all others why it should not at the same time control wages. The control of both, when added to all the regulation now indulged in, and which may hereafter be indulged in, would mean practically government ownership without payment for the property and without direct governmental responsibility for the management of the roads. It would mean, that while refusing the responsibility and the cost of government ownership, the legislature was undertaking to disrupt the fundamental conditions upon which alone private ownership and management can succeed.

If we look at the generalization regarding the power of Congress and the state legislatures which must be approved if an act fixing the wages of railway employees be sustained as such, the difficulties of so holding consistently with the protection of the fundamentals of the social order from the power of the legislature, becomes even more apparent. The narrowest generalization would be that the legislature has power to fix wages for all employees in the transportation service. But no distinction could be made between railways and telephones and telegraphs and other methods of communication by public service corporations, so that the fixing of wages in the whole field of the business of intercommunication, carried on by public service corporations, would be open to the legislature. Further-

4I (IgI6) 30 HARV. L. Rev. 63. 
more, no distinction could be made between the power to lower and the power to advance wages. Such a power would be quite as much a menace to the freedom of labor managers who control the collective bargaining for the sale of labor, as it is to the freedom of the managers of property who purchase labor. It is clear also that so far as the fixing of wages is concerned, no distinction is to be made between public service corporations engaged in the business of transportation or communication, and any other business. So far as the power to fix rates is concerned, such a distinction has been made, but there is no ground for making it, so far as the payment for labor or any other commodity required is concerned. No distinction can be made between the price of labor and the price of commodities. A power to fix the price of labor would logically include the power to fix the price of commodities. Thus if the Adamson Law be looked upon as a wage-fixing act merely, the sustaining of it would lead to the generalization that Congress has power (provided that the act be not confiscatory) to fix wages and prices of commodities in every industry. Such a power, if exercised, would certainly strike at the fundamentals of our present industrial and commercial social order as they lie in the mind of the court. The existence of such a power would open an unobstructed way for an attack upon our social order by a majority at any time. It is the business of the court to see that such a path is obstructed. This is not an argument from the abuse of power. It is an argument as to the extent of a power, which the necessity of generalizing from a particular decision would require the court to recognize if it sustained what was merely a wage-fixing act.

Suppose, however, the Adamson Law is not a mere wagefixing act at all, but an act to compel the railways to try an experiment from which may be derived data to be used by them and the unions in adjusting their bargaining as to wages, and by the government and the public to guide them in their attitude or course of action. If this were the predominant effect of the act, then, if it were sustained, the generalization of the court would be merely that the power of the legislature was not so limited that it could not require an experiment for an appropriate length of time for the purpose of securing the information in question, and place the expense of the experiment (if not confiscatory) upon the employer. Suppose such an experiment would make good the manager's case. That would tend to head 
off government ownership and to promote compulsory arbitration in case the employees were persistent in their refusal to accept the terms which the experiment showed to be equitable and proper. Public opinion would be enlisted on the side of the managers. The employees themselves would obviously be more willing to come to the terms found by the experiment to be just. Managers who would refuse an experiment bringing in such returns would obviously be so stupid and short-sightedly selfish as to need the prod of legislation to make them do what was in their own interest. Suppose, however, the experiment made a clear case against the managers. That would give the managers information which they might not have possessed before to aid them in their collective bargaining. It would guide the public in the formation of its opinion. It would give the legislature much needed information to enable it to determine whether, if the railroad managers persisted in a refusal to accede to just demands, government ownership might not be necessary. In any event the public welfare-and indeed the very social structure about which so much is here said-depends upon its transportation system. An act, the predominant effect of which is to require an experiment which will tend to prevent the disruption of that system by furnishing the parties, public, and the government with information, can hardly be condemned on the ground that it is inimical to the social order itself. ${ }^{42}$

It is submitted that the Adamson Law is not a mere wagefixing act but an act requiring an appropriate and reasonable experiment to be made by the railroads, and is, therefore, in and

\footnotetext{
"In the recent case of State v. Public Service Commission (IgI7) IgI S. W. (Mo.) $4 \mathrm{r} 2$, the court sustained an order of the commission fixing lower rates for a gas company temporarily, merely to make a test, in order that the real question of a reasonable rate might ultimately be determined. Here the commission which ordered the experiment had power to fix rates. It was, therefore, securing information for the purpose of carrying out its own power. Does it make any difference that Congress secures information which cannot be used by it to fix wages? Congress would have power to act upon the information obtained in other ways than fixing wages, i. e., by taking steps toward government ownership. The parties and the public will certainly act upon any information obtained. Does not the government take a census in order to secure information for general purposes? Does not the census act take the liberty of those who are compelled to answer questions, and the liberty and property of those who are imprisoned or fined for refusal to do so? See U. S. Sts. at I. 6rst Cong. Sess. I, chap. 2, secs. 23, 24.
} 
of itself, "due process of law." Several considerations make it easy to reach this conclusion.

A general transportation strike was threatened. No one knew what the merits of the controversy were. Apparently the subject matter of the dispute was so intricate that the legislature was at least entitled to assume that no one could know without some actual experiment being made. The act provides for an experiment. In laying down the Eight-Hour day as the measure of a day's pay, and requiring that wages be not reduced, it fixes the general outlines of the experiment. Then the act provides for the appointment of a commission to report upon the results of the experiment within a reasonable and appropriate time, that is to say, not less than six, nor more than nine months. Thirty days after the report is in, the provision prohibiting a reduction in wages comes to an end. The railroads may then reduce wages as they please. The employees may strike, but the public will have the commission's report to go upon. The form and operation of the act is entirely consistent with the theory that it provides only for an experiment which will give important information to all parties in interest.

It will no doubt be argued that if the act merely directed an experiment, why require the wages at the old rate to be paid over to the employees? Why not merely hold up wages and have them paid over at a future time if the commission found they should be? There are several answers to this. First, any such arrangement would have led to the charge that the act was in fact a wage-fixing statute pure and simple, because it would have provided after the experiment had been made, for the payment over of the higher wage. Second, if the money were not actually paid over at any time, the experiment would have been a sort of moot case-a mere experiment in bookkeeping. It would have lacked reality. As it is now, the wages which the experiment calls for are actually to be paid over, not at all because the legislature is fixing wages, but in order to make an experiment, and to make it a real one, with all the readjustments which such a change would naturally provoke.

It may be urged that it would have been fairer for the public to pay the cost of the experiment, or to have required the Interstate Commerce Commission to raise rates in order to reimburse the railways, in part at least, for the expense of the experiment. Perhaps so! But Congress undertook to say that the cost of 
this experiment (except that of the commission and its incidental expenses) should be borne by the railways themselves. The court cannot say that the cost of such an experiment was improperly thrown upon the railroad. Once concede that such an experiment is a proper subject of legislation so that the act may itself be "due process" and the fact that the cost is thrown on the railroad, is not different from the placing of the cost of new methods of accounting or safety appliances on the railroad. The railroad is protected, as far as it can be by the courts, by the rule that the expenditures required shall not be confiscatory.

CONCLUSION

The following suggestions are made for the guidance of lawyers engaged in dealing with the constitutionality of acts of the legislature under the "due process" clause where the only process is the mandate of the act itself:

(I) So far as "due process of law" is concerned, the only limitation upon the legislature is that an act depriving any person of liberty or property is void, when, upon the balancing of all the interests, the predominant effect of the act is such that any generalization resulting from sustaining it will open an unobstructed way for attack by the legislature upon a fundamental condition of the existence of the social order.

Perhaps the same idea may be stated more conventionally as follows: Acts depriving any person of liberty or property are arbitrary and void if they have no substantial and rational or reasonable relation to the health, safety, morals, or welfare of the public or a part of the public. Whether the act has such "substantial and rational" or "reasonable" relation to the objects enumerated is determined by balancing all the interests and determining whether the predominant effect of the act is such that any generalization resulting from sustaining it will open a way for attack by the majority upon a fundamental condition of the existence of the social order.

(2) If the determination of the application of such a formula is left to be decided upon the face of the act and such facts as the court takes judicial notice of, the balancing of interests may be attempted upon such partial and incomplete data as will 
require one decision, when upon a complete presentation of the conflicting interests, the result would be different. Therefore, the case upon the balancing of the interests should be built up by each side with all the data of which the court will take judicial notice and the actual proof of other material facts properly incorporated in the record.

(3) Whoever may have the burden of proving facts which show the act to be valid or invalid, the burden of going forward with evidence or facts of which the court takes judicial notice may shift from one party to the other. If the case is decided upon the face of the act and such facts as the court takes judicial notice of without looking further than its own experience and general knowledge, one result may be required. If many facts are brought to the attention of the court by the presentation of sources of which it takes judicial notice, a different result may be reached. If, however, actual evidence is presented respecting the particular business or industry affected in the particular locality where the legislation is operative, the court might properly go back to its first position.

(4) What are the "fundamental conditions upon which the existence of the social order rests" should not be left entirely to the "judgment," or "intuition," or visceral sensations of the judiciary. In short, they should not, so far as counsel are concerned, continue to be "the inarticulate major premise." They should be discussed and arguments made as to whether such a fundamental condition is involved. The fact that the court in its opinions will continue to leave the major premise inarticulate should not be a cause for discouragement. The silence of the court in its public utterances is based upon obvious reasons of policy. In the conference room there will, no doubt, be much appreciation of the efforts of counsel to articulate the major premise.

Albert M. Kales.

HaRVARD LAW ScHool. 